\title{
Article
}

\section{Snapshots of Selfhood: Curating Academic Identity through Visual Autoethnography}

\author{
Hunter, Anna Clare
}

Available at https://clok.uclan.ac.uk/32979/

Hunter, Anna Clare orcid iconORCID: 0000-0003-4202-920X (2020) Snapshots of Selfhood: Curating Academic Identity through Visual Autoethnography. International Journal for Academic Development, 25 (4). pp. 310-323. ISSN $1360-144 X$

It is advisable to refer to the publisher's version if you intend to cite from the work. http://dx.doi.org/10.1080/1360144X.2020.1755865

For more information about UCLan's research in this area go to http://www.uclan.ac.uk/researchgroups/ and search for <name of research Group>.

For information about Research generally at UCLan please go to http://www.uclan.ac.uk/research/

All outputs in CLoK are protected by Intellectual Property Rights law, including Copyright law. Copyright, IPR and Moral Rights for the works on this site are retained by the individual authors and/or other copyright owners. Terms and conditions for use of this material are defined in the policies page.

\section{CLoK}

Central Lancashire online Knowledge www.clok.uclan.ac.uk

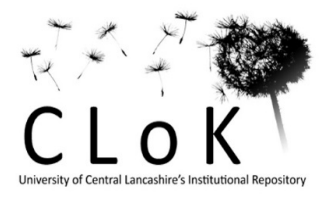




\section{Snapshots of Selfhood: Curating Academic Identity through Visual Autoethnography}

\section{Anna Hunter}

Centre for Collaborative Learning, University of Central Lancashire, Preston, United Kingdom

Media Factory ME429, University of Central Lancashire, Preston, UK PR1 2HE

ACHunter1@uclan.ac.uk

@annachunter

ORCiD ID: https://orcid.org/0000-0003-4202-920X

Dr Anna Hunter is a Senior Lecturer in Academic Development at the University of Central Lancashire. 


\section{Snapshots of selfhood: Curating academic identity through visual autoethnography}

Academic identity is fluid, slippery and uncertain; academic developer identity even more so. This paper explores the author's use of photography as a medium through which to present, represent, and interpret her own practice and professional identity as a third space professional within Higher Education (Whitchurch, 2008). Drawing on existing literature on academic identity, the author explores the way in which she has attempted to negotiate her identity as an academic developer through photographs that represent milestones in the construction of this identity. As a methodological framework the discussion of these pictures draws on autoethnographic approaches to identify formation, combined with visual narratology, in the form of visual autoethnography.

Keywords: academic identity, academic development, photography, autoethnography, visual narratology

\section{Introduction}

A leafy pin badge skewered to a rainbow; a conference ID badge; a presenter in full flow. This collection of images is one that demonstrates my attempt to curate academic identity via social media, through the sharing of images that enable me to construct and narrate a public version of my professional self. Through a critically reflective engagement with these images, I seek to explore the use of visual autoethnography as a tool for identity formation, drawing on established research in the field of academic identities and autoethnographic methodologies as a means of negotiating the ontological uncertainty experienced by the third space profession of academic development (Kensington-Miller et al 2015; Whitchurch, 
2008). In this paper, I review the existing literature around the instability and uncertainty of academic identity, considering what it takes to forge a sense of professional academic selfhood within the supercomplex world of the contemporary university (Barnett, 2000; 2004); the discussion then turns to the peculiar case of academic developer identity, 'the chameleon on the tartan rug' (Kensington-Miller et al, 2015), inhabiting a liminal space between academic and professional. I discuss my methodological approach, drawing on the history of autoethnography as a tool for exploring academic identity, before investigating the potential of visual autoethnography as a means of identity-work. The photographs cited at the outset of the paper form the basis of my analysis, as I seek to explore and understand the ways in which I publicly construct my identity as an academic developer through images and visual narratives of professionalism, and what this act of curation suggests about academic developer identity more widely. Finally, I consider the future application of this work within academic development practice.

\section{Academic Identity: Becoming and Un/becoming}

Writing on the experiences of younger academics, Archer (2008) notes that 'academia is a contested territory that entails constant struggles over the symbols and boundaries of authenticity' (p. 386). The notion of authenticity, and the lack of it, is central to much of the discussion around academic identity over the last ten years, speaking as it does to the welldocumented experience of imposter syndrome (Brems et al 2016; Knights and Clarke, 2014; Parkman, 2016). Quigley (2011) observes that 'at best one can describe academic identity as a constantly shifting target, which differs for each individual academic' (p. 21).The notion of academic identity as a 'shifting target' seems to bely the agency of the academic in his or her identity formation, suggesting that the boundaries of what constitutes academic identity are 
set by an/other, and that in order to experience a sense of academic identity the individual has to meet targets that are not of their own making. Knights and Clarke, alternatively, suggest that '[within organisations] subjects assemble and reassemble their identities... [and] choose from a variety of discourses (Kuhn, 2009) that intersect, and are often antagonistic, contrary or ambiguous' (2014, p. 337), which although implying some lack of agency in terms of the discourses that are available to them, and in how these intersect, also suggests that the individual academics are ultimately responsible for which discourses they choose to inhabit. Certainly, as Archer (2008) argues, the impact of neoliberalism in higher education has been to produce an environment in which “ "becoming” an academic ... can also involve conflict and instances of inauthenticity, marginalisation and exclusion' (p. 387). Archer follows Colley and James (2005) in describing academic identity as a "disrupted process", which involved not only "becoming" but also "unbecoming"; a process that is paradoxical, impossible, 'a desired yet refused subject position' (Archer, 2008: p. 287). Much of this inauthenticity may be ascribed to the neoliberal impulse towards performativity, with many of Archer's interview subjects commenting that they were reduced to a sum total of papers published and grants won. Within such a performative framework:

the capacity to be seen as an authentic, successful academic is tightly constrained and dependent upon the extent to which the academic can keep delivering (producing the "right" goods) as a neoliberal subject (p. 392).

Agency in identity formation is possible, but difficult, messy and contested. The neoliberal discourse of performativity is at odds with the romantic notion of knowledge formation for its own sake. Many academics may thus have to make a stark choice between their passion and their profession, choosing an inauthentic academic identity in order to provide for the authentic identity that is concerned with the work that nourishes the soul. 


\section{Academic Developer Identity}

In further exploring this aporia, Henkel (2005) locates academic identity in terms of how an individual is able to relate to two distinct, but often overlapping, communities: the discipline and the higher education institution. Taking the discipline as a starting point, Henkel suggests that 'disciplines are given tangible form and defined boundaries in the basic units or departments of universities and their role in the shaping and the substance of academic identities is there reinforced' p.158). This approach is problematized however by the experience of academics that do not, or cannot, align with a clearly delineated 'home' discipline. Such is the plight of academic developers, who often arrive at academic development as a secondary discipline, having begun academic careers in another subject. Academic developers are often described as liminal characters, inhabiting a space that is neither fully academic or entirely a professional service role (Kensington-Miller et al, 2015). They are variously employed on academic, professional or even managerial contracts, and in such marginal spaces feelings of inauthenticity thrive.

Often academic development, which according to Samuels (2013) has achieved the status of a discipline in Higher Education, inhabits a physically liminal or marginalised space within higher education structures. Centres for Excellence in Learning and Teaching, or alternatively titled discrete academic development units, are increasingly common within the organisational structures of HEIs, but again there is little consistency across the sector in terms of whether these units are considered academic departments in their own right, professional services units, or, in my own case, a blend of the two (echoing Whitchurch's conception of the 'third space' academic professional). Being a perpetual outsider, both conceptually and physically, confers a sense of freedom to some extent, as academic developers occupy an organisational position in which they are able to engage in critical 
conversations and provide critical friendship to those in more 'traditional' academic positions (Kensington-Miller et al 2015; Rowland 2007), however this freedom is tempered by the uncomfortable likelihood of being viewed as agents of management discourse, driving the neoliberalist agenda through checks and measures on the 'quality' of teaching and learning. There is a real and present danger for academic developers of being seen by colleagues as a tool or function of new public managerialism. Both Quigley (2011) and Kensington-Miller et al (2015) cite Whitchurch 2009's conception of the blended professional, however whereas Kensington-Miller et al's discussion seeks to explore the ontological potentiality of the liminal spaces inhabited by academic developers, Quigley places an emphasis on 'the emergence of specialists in areas such as marketing and enterprise, and on their positioning as “managers"” (p. 26). Tellingly, Quigley offers a reflective framework for exploring academic identity in which external agencies such as the Higher Education Academy (explicitly referenced) pose a challenge to the construction of academic identity. As an academic developer, however, I find in my professional recognition by the HEA/AdvanceHE a means of validation that, conversely, reinforces my identity and legitimises my role in developing teaching and learning. Is my role as an academic developer then aligned to the performative neoliberalist agenda that, for Archer, is anathema to authentic academic identity? How do I reconcile the idea that my own academic identity may be built on practices that challenge and threaten the identity-work of others?

Given the liminality of the role of academic development within the academy, it is perhaps no great surprise that academic developers find themselves in need of time and space to make identity-work happen and to consider the ontological nature of their roles: 'if the identities of academic developers are difficult to define or indeed are problematic, and they lack agency, how do they deal with and maintain the multiple components of their identity and practice?' (Kensington-Miller et al, 2015, p. 9) Kensington-Miller et al speak evocatively 
of conducting 'the necessary self-maintenance and identity work' (p. 10); in this paper I am exploring my own identity work that takes place through the visual framing and sharing of my practice and the narratives of professional identity that I construct through photography and share via social media. This is a tale not only of academic identity, but rather of academic ontology, that is how academics (and academic developers) come to be (Quigley, 2011).

\section{Methodology}

\section{Autoethnography}

In order to reflexively explore the public construction of my academic identity using images drawn from social media, autoethnography appealed as a methodological approach in a number of ways. The use of visual, rather than linguistic narrative as the primary source material led me to the possibility of visual autoethnography as a particularly useful means of exploring lived experience through photographs and other images; but the history and development of autoethnography as a qualitative research method also speaks loudly to the identity-work being conducted here.

Fernanda Duarte (2007), who has explored the use of autoethnography as a tool in the scholarship of teaching and learning, cites Ellis and Bochner (2000) in claiming that 'autoethnography is an "autobiographical genre of writing and research that displays multiple layers of consciousness, connecting the personal to the cultural"' (p. 2). In essence, autoethnography is a reflexive, qualitative research process within which the researcher becomes his or her own subject, writing reflectively and autobiographically (auto) in order to draw conclusions about a particular culture or experience (ethnography). The concept of autoethnography first arose in the 1970s, and originated as a means of distinguishing 'between cultural insiders and outsiders' (Adams et.al, 2017); in these origins we can observe the implied suitability of autoethnography for investigating academic identity formation and 
particularly academic developer identities, given the contested status of academic developers as simultaneously insiders and outsiders. Autoethnographic research is characterised by 'the back and forth between the personal and the cultural' (Jones et.al, 2012, p. 703), and it is in the reflexive spaces between the personal and the cultural that insights may be found into the impact of societal structures of power on individual identity.

At the centre of autoethnography is narrative: 'Autoethnographic texts point out not only the necessity of narrative in our world but also the power of narrative to reveal and revise that world' (Holman Jones, 2005, p. 767). This is echoed in Holman Jones' writing on critical autoethnography (2016), in which she observes that 'there is a vital, yet often unrealised relationship between storytelling and critical approaches to autoethnography' (p. 228). Holman Jones cites Joan Didion's claim that 'we tell ourselves stories in order to live' (p. 230), again revealing the symbiosis of narrative and identity formation. In seeking to explain (and to some extent define) critical autoethnography, Holman Jones equates story with theory, and draws on the work of Judith Butler to claim that, within the process of critical autoethnography 'the intersection of theory and everyday language is crucial to telling and re-imagining not only what we can say, but also who we can be' (p. 229, italics in original). For Holman Jones, 'doing critical autoethnography engages us in processes of becoming and because of this, shows us ways of embodying change' (p. 229). The ontological turn inherent in these notions of nascent being and becoming return us to the challenges faced by academics, and in particular academic developers, in constructing meaningful professional selves that satisfy both the personal and the cultural conditions at play.

\section{Visual autoethnography}

For the purposes of this paper, I am using photographs as the reflexive prompt at the core of my autoethnographic research. This marks a departure from 'traditional' autoethnographic 
approaches, which tend to evolve from an analysis of the written word, or the linguistic narrative around an event, experience or phenomenon. Visual narrative, however, possesses a number of attributes that make it the ideal subject of autoethnographic enquiry. Mieke Bal (1997), writing on visual narratology, calls for 'the analysis of visual images as narrative in and of themselves' (p. 162), distinguishing visual forms of storytelling from the use of images as illustration to linguistic narratives. Bal discusses the way in which visual narratives are open to multiple interpretations, and are indeed already interpreted even at the point of consumption: 'what we see is before our mind's eye, it has already been interpreted' (p. 163). It could be argued that visual narratives are particularly well suited to autoethnographic approaches as the focalisation of the narrative is more open, more flexible than that of a linguistic text. In a reflective journal, for example, the narrative is only available through the filtered lens of the author; in a photograph, the intent of the photographer is one possible interpretation, but the viewer is also able to engage with the visual narrative through his or her own lens. In this research I am exploring my own, autoethnographic interpretation of the images under discussion, however the images remain open to alternative interpretations as the object of another's gaze. This multiplicity closely aligns visual autoethnography with identity work, as noted by Scarles (2010):

\begin{abstract}
Visual autoethnography offers pathways to realising the situatedness of self alongside others that encourages self-reflexivity and critical agency... [it] strives to access the multiplicity of truths that exist within a mesh of power relations. In embracing the multiplicities of self and other, it strives to move beyond discursive productions, productions of power and the propagation of knowledge that potentially limit expressions of self and other (p. 910)
\end{abstract}

In drawing on visual autoethnography's power to access, identify and mobilise multiplicities of self, through the subsequent analysis of my images I will be reflexively exploring how my own self is realised through the intent, composition and interpretation of each image. The analysis will inform further discussion around the nature of academic developer identity. 


\section{The Photographs}

\section{Context}

In my current role I am a Senior Lecturer in Academic Development, within a Centre for Excellence in Learning and Teaching in a large post-1992 university. I have been employed within the same institution for thirteen years, and during this time I have experienced a number of restructures and periods of uncertainty regarding my role within the university. The photos under analysis in the following discussion tell the story of my attempts to construct and assert my academic identity, and in doing so to restore a sense of authenticity to my practice. All of these images were taken between May and July 2018, at a time when my sense of professional self was in a period of flux. I was coming to the end of a programme of leadership development, and had recently been asked to take on leadership of a crossinstitutional academic development programme. Despite these external indicators of success, however, I still felt uncertain about my ability to perform my role. My internal sense of professional identity was conflicted; I was caught between the desire to take on more responsibility and continue to develop in my role, and the fear inherent within imposter syndrome that my perceived lack of ability would be 'found out'. During this time I became aware that I had developed a habit of taking photographs that showcased my professional achievements and sharing these images on Twitter, in a performative act designed to convince myself that I was truly enacting the role of an academic developer.

Gilpin (2010) identifies Twitter as 'a window into the complex processes of professional identity construction' (p. 232). Lending itself to ethnographic analysis, the use of Twitter by professional groups allows for creates an 'in-group/out-group dynamic' (p. 244), within which performative conversations occur that may 'indicate a desire to enter the core group from a peripheral tier' (p. 247). By carefully staging and selecting the images under 
discussion as a means of performing professional identity on Twitter, I had (unknowingly) demonstrated my desire to enter into the public professional space of academic development. In doing so I presented a curated version of my academic identity that is not perhaps a true reflection of what it is, but rather what I would like to it be. The discussion that follows is therefore not only an analysis of the narrative revealed by each photograph, it is also an exploration of the story that I wanted to tell by presenting these images in the way that I have. This reflexivity opens up a space in which we can use this analysis to consider the implications for academic developer identity more widely.

I will be providing a brief overview and commentary on each of the photographs in turn, before considering all four together in a more detailed analysis.

\section{SEDA Badge}

[Insert Figure 1 here]

In May 2018 I facilitated a session at the SEDA Spring Conference. SEDA is the Staff Educational Development Association, an international professional community for Educational Developers which fosters professional development, scholarship and support in the development of learning and teaching in HE. In the previous year I had achieved a longheld career goal of becoming a Fellow of SEDA; which for a long time had seemed to be out of my reach, given limitations in both remit and funding in my previous role. Upon arrival at the conference, I collected my conference badge with a sense of pride and belonging, as it clearly represented my SEDA Fellowship status with the post-nominal letters FSEDA. Facilitating a session for the conference was nerve-wracking, as I felt that I was exposing my fledgling practice to the world of experienced academic developers, but ultimately also immensely affirming, as the workshop was well received. In order to capture the moment I 
took a picture of my conference badge with the post-nominal letters clearly displayed; I wanted to feel like I belonged in that environment, and I wanted other people to be able to recognise that I belonged, for me this photo was a means of demonstrating that belonging.

Attempting to analyse the photograph with some objectivity, it strikes me that the positioning of the badge on top of the conference programme is telling. The focus of the photograph is supposed to be the post-nominal lettering, indicating the "belonging" described above, but there are other things that draw the eye as well. In a sense, I'm displaying my belonging in relation to two bodies - SEDA and my University; this belonging also carries some linkage to a sense of being, given that one 'is' a Fellow of SEDA (or of any organisation), there is an element of ontological shift about 'becoming' a Fellow. The positioning of the badge with the conference programme in the background suggests a location and a context for the picture, that being an academic conference, which perhaps adds a sense of prestige to the badge as well. The narrative of the picture is a story of belonging and value.

\section{Leaves and Rainbows}

[Insert Figure 2 here]

In 2017/18 I was given the opportunity to participate in the Aurora Women's Development programme, a leadership programme offered in the UK to women working in HE, in order to address the gender imbalance in HE leadership. Aurora demanded intense reflection that at times was exhausting, but which ultimately provided deep insight into who I am within my role, and where I might want to go with it. At the end of the Aurora workshops all the participants were given a pin badge representing the Aurora logo, to indicate that we are now alumni of the Aurora programme. I attached my badge straight away to my university lanyard, as this was an identity that I wanted to display. The lanyard itself reveals another 
facet of my professional identity: I have a leadership role in Equality and Diversity, and in developing inclusive learning and teaching. As part of this role I undertook LGBT Allies training, and the rainbow lanyard was awarded as a sign of that participation. The two together, the badge and the lanyard (the leaves and the rainbow) represent my personal and professional development over the last two years.

This is a narrative of growth, and it also signals continuity, centred to some extent on place. The rainbow flows from the left to the right of the picture, on a slightly upwards trajectory, which perhaps recreates a sense of positivity and ongoing opportunity to advance my practice. Certainly, the continuous lines of the rainbow create a dynamic movement within the image that suggests this process will continue. Juxtaposed against these lines however are the pin badge, and less noticeably the university logo which reminds the viewer that this is an advancement of practice that is located within, and facilitated by, a particular context. The pin badge draws the eye to the centre of the rainbow and represents personal development within the professional; my development through Aurora has been very much introspective. By situating what is essentially another marker of belonging that symbolises personal growth within the symbol of professional growth, the two are brought together in a synthesis that denotes a range of transformational opportunities.

\section{In full flow}

[Insert Figure 3 here]

I did not take this picture; rather, I am the subject of this photograph, in something of a departure from the previous images under discussion. I chose this picture for analysis within this research because it is an image that I share and display publicly on a regular basis, it is an image of myself that I enjoy; for these reasons I think that it is a worthwhile subject for 
analysis, as an image that I choose as a vehicle for constructing and disseminating my academic identity.

The picture was taken during my presentation at the SEDA Spring Conference 2018. I was not aware of the photographer in the room during my presentation, and therefore this image captured, quite candidly, an image of myself that I rarely get to see. In this photograph I am mid sentence, engaging with an unseen interlocutor in the audience. It seems as though I am gesticulating with a pen to emphasise my point, although I suspect I was holding the pen out of nerves, as a sort of tiny comfort blanket to focus my thoughts and my energy. As I did not take the picture I can claim no responsibility for or knowledge of why the picture is framed in the way that it is, or indeed why it was taken, however I can reflect on why I chose this picture out of the hundreds that were available for download, and why it has meaning for me. I chose this picture because it shows me in a way that I rarely see myself - I appear confident and effective in the momentary role of presenting my research to my peers; it enabled me to gain an objective view on my own capability, and I liked what I saw.

Like the previously discussed photograph of my Aurora pin badge juxtaposed with my LGBT Ally lanyard, this picture is dynamic. The movement and energy of the image is conveyed by the extended arm, which is further extended by the gesticulating pen. The subject (me) is captured in the midst of a speech act, sharing but also creating knowledge through interaction with the other (unseen) beings in the room. When I saw this picture it was at a moment in my career when I was wondering how I would proceed, what direction I might take. The dynamic energy of this image suggests a sense of confidence and competency, which served to remind me how much I enjoy engaging in research and the dissemination of ideas, it caused me to see myself through an academic lens as someone who is (dare I say) good at what she does, and who is capable of holding the attention of peers through the articulation of my work. 


\section{Oxford Road Station}

[Insert Image 4 here]

In June 2018 I was invited to showcase some of my work on collage making at a Creative HE Community meetup, which was held in Manchester. Manchester is a special place for me, as it is where I completed my $\mathrm{PhD}$ and where I have variously lived, worked, and travelled to since I my teens. This particular journey was all the more significant, because it seemed to signify my acceptance into the academic development community; once again, the sense of professional belonging that I had been chasing throughout these images. On arrival in Manchester I took a picture of the old station sign for Oxford Road station in order to record my physical journey on the day, and my personal journey in arriving at this point of sharing my work with colleagues from other universities.

When I review this picture at some temporal distance, the clear juxtaposition of the antiquated sign with the bright blue sky behind seems to indicate a sense of hope or optimism. This juxtaposition is heightened by the presence of a modern high rise building composed of glass and steel, rising behind the sign and reflecting the blue of the sky; in this way the image encapsulates both my own past and the future. The vertical lines of both the station sign and the modern high rise building behind it suggest an upward dynamism, a future direction of travel that implies continued growth. The sign itself features the familiar "British Rail" logo of two opposing arrows, this speaks not only to a past that is long gone and dissolving from conscious memory, but also the incessant movement of railway stations, the constant arrival and simultaneous departure that marked my years of travel in and out of Manchester, at a time when I did not have a clear future direction or a sense of where I might be going. In this image I clearly state "I have arrived".

\section{Analysis}


Considering all of these images together, as a curated collection, it is immediately noticeable that they represent positive experiences, achievements and professional successes. This is a frequent characteristic of images shared on social media, as Gilpin notes: 'information shared in fluid, public, online venues such as Twitter is frequently the result of a more or less conscious decision to share only information which brings the greatest gain, in terms of social capital or professional reputation' (2010, p.244). Insofar as these images are skewed towards the positive, they do not present an accurate picture of my academic development practice, but they do provide insight into how I wish to present that practice within my professional community. Imposter syndrome is rife in all aspects of academia and academic developers are by no means immune from it; these images act as a reminder that, despite my own misgivings, I 'belong' in this academic sphere. That I share them publicly speaks to a need for external validation of that, indeed this desire is evident in all of the images. It is interesting to note that all of these images were taken outside of my own institution, suggesting that I seek (and find) affirmation of my role externally, through engagement with the wider academic development community. This reflects the importance of external networks for academic developers; where our individual academic identities are unstable or unknowable within our institutions, we are able to better position them by using other academic developers as reference points. This interaction often occurs through social media: 'Public interaction with others, including posts about offline professional events and social interaction with other practitioners, contributes to building an identity as an entrenched professional' (Gilpin, 2010, p.246). The shared construction of academic identity in this manner subsequently works to establish a coherent identity for the profession as a whole: 'constructing a professional identity also means constructing the identity of the profession, especially a profession in a state of flux' (p.234). 
These images also reveal the importance of labelling, of being able to put a name to identity, which represents another ontological shift that has impacted greatly on my identity and how I position myself within the university. Kreber (2004) writes that academics often devalue their knowledge about teaching because it is learned experientially, and is often tacit rather than explicitly known. I wonder now if this has also been the case for myself and my academic development practice, which has evolved over many years. I did not become an academic developer suddenly when I adopted the title; nonetheless I, and potentially other academic developers, conduct our professional practice in such a way as to be sometimes tacitly, rather than overtly, influential within university teaching and learning practices, inhabiting the uncanny third space discussed earlier. Here then is an inherent tension between the epistemological and ontological state of academic developer identity: whilst I tacitly accept the knowledge that I am employed as an academic developer, I do not explicitly feel myself to be one. The public performance of this identity curated through social media reflects not only my own effort to construct a viable account of myself as a successful academic developer, it also speaks to the persistent need for re-affirmation that arises when one's academic identity is constantly in dispute.

\section{Conclusion}

Although Autoethnography is not a research method that is used to provide widely generalisable data, it does seek to infer trends, patterns and phenomena across a culture based on the analysis of personal experience. My autoethnographic analysis of these images reveals an ontological journey of "coming to be", which suggests that I rely on external affirmation of both my identity and my capability and that I seek external symbols of success as anchor points to help me locate myself within my role, within the university, and within Higher Education more broadly. The danger of relying on external affirmation to denote identity is 
that one lacks agency in the construction of one's own professional identity (calling to mind Quigley's metaphor of 'a shifting target' (2011, p.21), which leads to insecurity, vulnerability and inauthenticity. In this, we can again see the impact of the neo-liberal condition within Higher Education, which presents in its emphasis on seemingly arbitrary performative measures, as a state of ontological uncertainty surrounding the academic as well as the academic developer. Of particular interest in this analysis is the powerful impact of the third photograph, in which I was the subject of the image. Recalling Archer's description of academic identity as 'a desired yet refused subject position' (2008, p. 287), this image afforded me the opportunity to see myself as the subject of my own narrative of identity formation, and as such restored some of the agency that had been lacking from the analysis of the previous images. In positioning myself as my own subject in this manner I am able to more concretely claim my identity, not by virtue of a badge or a title, but by expressing my professional identity through a narrative act of being: in that image I see myself being an academic developer, thus I am able to claim the role, and more fully believe it. Although this analysis speaks to my personal experience of identity formation only, it is possible to infer that academic developer identity more widely can be reclaimed through an ontological focus on being, rather than on an epistemological labelling of the profession and the individuals within it. The use of visual autoethnography here has been instructive in teaching me how I present my academic identity to the world, and equally how I narrate it to myself privately. I am interested to further explore the potential of this methodology as a tool to support my practice in Academic Development, and to support colleagues who equally struggle with multiple professional selves; the next step for this research will therefore be to make use of visual autoethnography within my work on the first module of a PGCert Academic Practice, to encourage new academics to capture images of their work as a tool for academic identity 
formation and confidence building, with the aim of encouraging them to develop their own subjectivity within narratives of identity and academic professional practice.

\section{Disclosure Statement:}

No financial interest or benefit has arisen from this research

\section{References}

Adams, T.E, Ellis, C. \& Holman Jones, S. (2017). Autoethnography. In Matthes, J., Davies, C.S. \& Potter, R.F. (Eds.), The International Encyclopedia of Communication Research Methods. DOI: 10.1002/9781118901731.iecrm0011.

Archer, L. (2008). Younger academics' constructions of 'authenticity', 'success' and professional identity. Studies in Higher Education, 33(4), 385-403.

Bal, M. (1997). Narratology ( $2^{\text {nd }}$ Edition). Toronto: University of Toronto Press.

Barnett, R. (2000). Realising the University in an age of supercomplexity. Buckingham: Open University Press

Barnett, R. (2004). Learning for an Unknown Future, Higher Education Research \& Development, 23(3), 247-260.

Brems, C., Baldwin, M.R., Davis, L., \& Namyniuk, L. (1994). The imposter syndrome as related to teaching evaluations and advising relationships of university faculty members. The Journal of Higher Education, 65(2), 183-193.

Colley, H., \& James, D. (2005). Unbecoming tutors: Towards a more dynamic notion of professional participation. Paper presented at Changing teacher roles, identities and professionalism Seminar Series, King's College London (January 2005-July 2006). 
Duarte, F.P. (2007). Using autoethnography in the scholarship of teaching and learning: Reflective practice from 'the other side of the mirror'. International Journal for the Scholarship of Teaching and Learning, 1(2), Article 21.

Ellis, C., \& Bochner, A.P (2000). Autoethnography, personal narrative, reflexivity: Researcher as subject. In Denzin, N.K, \& Lincoln, Y.S, (Eds.) Sage Handbook of Qualitative Research (2 ${ }^{\text {nd }}$ Edition, pp. 733-768). Thousand Oaks, California: Sage.

Gilpin, D. R. (2010). Working the Twittersphere: Microblogging as professional identity construction. In Papacharissi, Z., (Ed.) A Networked Self: Identity, Community and Culture on Social Network Sites (pp. 232-250). London and New York: Routledge.

Henkel, M. (2005). Academic identity and autonomy in a changing policy environment. Higher Education 49(1-2), 155-176.

Holman Jones, S., (2005). Autoethnography: Making the personal political. Denzin, N., \& Lincoln, Y., (Eds.) Sage Handbook of Qualitative Research ( $3^{\text {rd }}$ Edition, pp. 763-791). Thousand Oaks, California: Sage.

Holman Jones, S., (2016). Living bodies of thought: The 'critical' in critical autoethnography. Qualitative Inquiry 22(4), 228-237.

Jones, S.R., Kim, Y.C. \& Skendall, K.C. (2012). (Re-)Framing authenticity: Considering multiple social identities using autoethnographic and intersectional approaches. The Journal of Higher Education, 83(5), 698-724.

Kensington-Miller, B., Renc-Roe, J., \& Morón-García, S. (2015). The chameleon on a tartan rug: adaptations of three academic developers' professional identities. International Journal for Academic Development, 20(3), 279-290.

Knights, D. \& Clarke, C. (2014). It's a bittersweet symphony, this life: Fragile academic selves and insecure identities at work. Organisation Studies 35(3), 335-357. 
Kuhn, T. (2009). Positioning Lawyers: Discursive resources, professional ethics, and identification. Organisation 16, 681-704.

Parkman, A. (2016). The imposter phenomenon in higher education: Incidence and impact. Journal of Higher Education Theory and Practice, 16(1), 51-60.

Quigley, S. (2011). Academic identity: A modern perspective. Educate 11(1), 20-30.

Rowland, S. (2007). Academic development: A site of creative doubt and contestation. International Journal for Academic Development, 12(1), 9-14.

Samuels, P. (2013). Promoting learning development as an academic discipline. Journal of Learning Development in Higher Education 5, 1-22.

Scarles, C. (2010). Where words fail, visuals ignite: Opportunities for visual autoethnography in tourism research. Annals of Tourism Research 37(4), 905-926.

Whitchurch, C. (2008). Shifting identities and blurring boundaries: The emergence of third space professionals in UK higher education. Higher Education Quarterly, 62(4), 377-396. 
Figure 1. Photograph taken by the author.

Figure 2. Photograph taken by the author.

Figure 3. Photograph taken at the SEDA Spring Conference 2018, by Whole Picture Photography. Reproduced with permission.

Figure 4. Photograph taken by the author. 